\section{Physiological Responses of Greenhouse-grown Drip-irrigated Chile Pepper under Partial Root Zone Drying}

\author{
Harmandeep Sharma, Manoj K. Shukla ${ }^{1}$, and Paul W. Bosland \\ Department of Plant and Environmental Sciences, New Mexico State \\ University, MSC 3Q, P.O. Box 30003, Las Cruces, NM 88003
}

\author{
Robert L. Steiner \\ Applied Statistics and International Business Department, New Mexico State \\ University, MSC 3Q, P.O. Box 30003, Las Cruces, NM 88003
}

Additional index words. 'NuMex Joe E. Parker', photosynthetic rate, stomatal conductance, root length density, stem water potential, capsaicinoid concentrations

\begin{abstract}
Water saving, productivity, and quality of the chile pepper were evaluated under three irrigation treatments. Three drip irrigation treatments used were 1) control, where water was applied at the surface using two drip emitters; 2) partial root-zone drying vertically $\left(P R D_{v}\right)$, where subsurface irrigation was applied at $20 \mathrm{~cm}$ depth from soil surface; and 3) partial root-zone drying compartment $\left(\mathrm{PRD}_{\mathrm{c}}\right)$, where roots were divided into two compartments and irrigation was applied to one of the compartments on every alternate-day cycle for 15 days. Continuous measurements of soil water content were carried out during the growing seasons of 2013 and 2014, respectively. During both growing seasons, the stomatal conductance $\left(g_{S}\right)$ and net photosynthetic rates $\left(P_{n}\right)$ were similar among all treatments including the control. In both PRD treatments, a higher rooting depth and root length density (RLD) than the control likely compensated for the water stress in dry soil zones by taking up more water from the water available parts of the root-soil system. In $P R D_{c}$ and $P D_{v}$ treatments, $30 \%$ less water was applied than control without significant changes to plant stress expressed by stem water potential, plant height, capsaicinoid concentration, and yield. The increased irrigation water use efficiency (IWUE) demonstrated water saving potential of both PRD techniques for chile pepper production in water-limited arid environments.
\end{abstract}

Chile pepper (Capsicum annuum L.) is an important commercially cultivated crop in many countries including China, Mexico, Korea, and United States. United States ranked fifth among top 20 chile-producing countries with $918,210 \mathrm{t}$ of production. In United States, New Mexico is the leading producer of hot peppers (Murray, 1999). Chile is a high-value cash crop of southern New Mexico, and in 2000 , chile ranked fifth for cash receipts from agricultural commodities in the state of New Mexico (Hall and Skaggs, 2003).

Chile cultivation is mainly conducted in warm, semiarid regions of the world, where water shortage is a major constraint for production (Dorji et al., 2005). Chile is one of the most susceptible horticulture crops to water

Received for publication 14 May 2015. Accepted for publication 19 June 2015.

This work was supported by the USDA National Institute of Food and Agriculture, Hatch project 1006850.

We thank New Mexico Agricultural Experiment Station and NIFA for support. Thanks are also due to VPR's GREG program for graduate student support and Nakayama Chair endowment.

${ }^{1}$ Corresponding author. E-mail: shuklamk@nmsu. edu. to one of the compartments in vertical split, whereas alternately to each compartment in a laterally split system. Irrigation can be adjusted depending on the crop conditions, evaporative demands, and water balance (Saeed et al., 2008). PRD has been applied to several crops and has shown to reduce the crop water use, maintain yield, and improve water use efficiency (Stoll et al., 2000) of tomato; Lycopersicon esculentum L. (Zegbe et al., 2004), hot peppers; Capsicum spp. L. (Cheng et al., 2008), cotton; Gossypium spp. L. (Tang et al., 2005), and potato; Solanum tuberosum L. (Saeed et al., 2008). Besides water savings, increases in crop quality such as sucrose concentration in grapes, and fruit size, and edible fraction in mango are also reported (Spreer et al., 2007; Stoll et al., 2000).

Plants under PRD treatments meet their water demand by taking up more water from wetter parts of the root zone, thus compensating for the lower water availability in the drier part of the root zone (Zegbe et al., 2004). In grapevines, compensation was shown by redistribution of deuteriumenriched water from roots in wet soil to roots in dry soil under split-root system (Stoll et al., 2000). In pecan trees, compensated water uptake increased from deeper depths as upper soil became drier (Deb et al., 2011). Other studies reported the enhanced root water uptake from wetter soil zones to compensate partial drying of upper part of the root zone (Green and Clothier, 1999; Green et al., 1997). Higher root length, root biomass, and RLD were observed in PRD treatments than conventional irrigation (Gallardo et al., 1994; Songsri et al., 2008).

PRD can affect plants at morphological, physiological, biochemical, and molecular level (Sepaskhah and Ahmadi, 2010). However, no data are available on the effects of PRD drip irrigation practices on growth, physiology, and yield of chile under greenhouse conditions. The objective of this research was to investigate the hypothesis that macroscopically PRD would result in water savings while sustaining chile growth and yields. In this study, only the effects of water stress on physiological and morphological aspects of the plants were studied because these factors are directly related to crop yield (Liu et al., 2005). The concentration of capsaicinoids was also determined because increased capsaicinoid concentration in chile was reported due to water stress along with other environmental factors such as high temperature, light, and inadequate nutrients (Phimchan et al., 2012; Rahman and Inden, 2012; Zamora et al., 2013).

\section{Materials and Methods}

Experimental setup. This study was carried out in New Mexico State University greenhouses located in Las Cruces, NM $\left(32.2830^{\circ} \mathrm{N}\right.$ lat. and $106.7480^{\circ} \mathrm{W}$ long. at an elevation of $1186 \mathrm{~m}$ above sea level). The study was carried out for two consecutive growing seasons, i.e., 2013 (Feb.-Oct. 2013) and 2014 (Oct. 2013-May 2014). The New Mexican pod-type cultivar, NuMex Joe E. Parker (C. annuum), was used. Sowing was 
done in germinating trays using professional growing mixture on $14 \mathrm{Feb} .2013$ and 8 Oct. 2013 for each growing season, 2013 and 2014 , respectively. Once plants reached 810 true-leaf stage, they were transplanted into containers ( $26 \mathrm{~cm}$ diameter and $70 \mathrm{~cm}$ depth). The mean air temperatures and relative humidity inside greenhouse were $25.32{ }^{\circ} \mathrm{C}$, $23.60{ }^{\circ} \mathrm{C}$ and $43.37 \%, 41.43 \%$ during the growing seasons of 2013 and 2014, respectively. Soil used in this study consisted of 1:1:1 by volume mixture of sand, loam, and peatmoss. Soil mixture was first pasteurized in electric soil sterilizer at $60{ }^{\circ} \mathrm{C}$ for $30 \mathrm{~min}$ and was cooled to the room temperature before packing in the containers. Packing was done manually in 5-cm depth increments to obtain a homogeneous profile with an overall density of $1.01 \pm 0.02 \mathrm{~g} \cdot \mathrm{cm}^{-3}$. The bottom of each container was perforated and perforations were covered with mesh $(5 \times 5 \mathrm{~mm})$ to prevent soil loss.

Irrigation treatments. Three drip irrigation treatments applied to container-grown chile were control, $\mathrm{PRD}_{\mathrm{v}}$, and $\mathrm{PRD}_{\mathrm{c}}$. Irrigation was applied every alternate day (skipping $1 \mathrm{~d}$ ) around $8 \mathrm{Am}$ in all containers during 2013. One liter of water was applied in control containers by two drip emitters (adjustable 0-114 LPH@103-207 kPa Mini Bubbler) placed on the container surface. $\mathrm{PRD}_{\mathrm{v}}$ containers were irrigated with the same amount of water (i.e., 1 L) using two subsurface drip emitters placed at $20 \mathrm{~cm}$ depth from the soil surface. Thus, the top $33 \%$ of the root system was exposed to soil drying or soil wetting only via capillary rise. $\mathrm{PRD}_{\mathrm{c}}$ containers have split-root system, and the roots were divided during transplanting by gentle opening of root ball with hands into two equal parts to grow into two separate compartments within a container. Irrigation was applied at the rate of $0.7 \mathrm{~L}$ every alternate day (skipping $1 \mathrm{~d}$ ) for 15 consecutive days to one of the compartments. Irrigation was switched to the other compartment for the next 15 consecutive days. PRD treatments were started $15 \mathrm{~d}$ after transplanting (DAT) during both growing seasons. Earlier studies have reported that $\approx 90-95 \mathrm{~cm}$ (plus rain) of water are required for maximum green chile yields under drip irrigation (Wierenga, 1983) and $92-95 \mathrm{~cm}$ under furrow irrigation (Sharma et al., 2012). Because no yield reductions were observed during 2013 growing season among treatments, irrigation was applied every $3 \mathrm{rd} \mathrm{d}$ (skipping $2 \mathrm{~d}$ ) around 8 AM during 2014 in all three treatments. One liter of water was applied to control, while 0.7 $\mathrm{L}$ was applied to $\mathrm{PRD}_{\mathrm{v}}$ and $P R D_{c}$ treatments during each irrigation. Because of different irrigation amounts and irrigation intervals, the total amount of water applied varied among treatments as well as among growing seasons (Table 1). Length of growing season was $156 \mathrm{~d}$ during 2013 and $135 \mathrm{~d}$ during 2014 (Table 1). Three replicates per irrigation treatment were used and additionally four containers per treatment were used for conducting monthly root analysis. All plants were fertilized with a $14 \mathrm{~N}-6.2 \mathrm{P}-11.6 \mathrm{~K}$

Table 1. Total amount of irrigation water applied $(\mathrm{cm})$ and growing season (days) among three treatments, i.e., control, partial root-zone drying vertically $\left(\mathrm{PRD}_{\mathrm{v}}\right)$, and partial root-zone drying compartment $\left(\mathrm{PRD}_{\mathrm{c}}\right)$ during both years 2013 and 2014.

\begin{tabular}{lcrrc}
\hline & \multicolumn{2}{c}{ Total amount of irrigation water applied $(\mathrm{cm})$} & & $\begin{array}{c}\text { Growing season } \\
\text { (days) }\end{array}$ \\
\cline { 2 - 4 } $\mathrm{Yr}$ & Control & $\mathrm{PRD}_{\mathrm{v}}$ & $\mathrm{PRD}_{\mathrm{c}}$ & \\
\hline 2013 & 118.83 & 118.83 & 83.18 & 168 \\
2014 & 80.38 & 55.04 & 55.04 & 135 \\
\hline
\end{tabular}

slow-release fertilizer (Scotts, Marysville, $\mathrm{OH})$ before transplanting. After transplanting, Liquinox fish emulsion $[5 \mathrm{~N}(0.5$ ammoniacal $\mathrm{N}, 3.5$ water soluble $\mathrm{N}$, and $1 \%$ urea $\mathrm{N})-0.44 \mathrm{P}-0.83 \mathrm{~K}]$ was applied to all plants.

Soil water content. Soil water content was measured using time-domain reflectometry sensors (CS616; Campbell Scientific, Inc., Logan, UT) and capacitance-based hydra probes (SDI-12; Stevens Water Monitoring Systems, Inc., Portland, OR) during 2013 and 2014, respectively. The containers under each of the control and $\mathrm{PRD}_{\mathrm{v}}$ treatments were instrumented with two sensors representing the soil depths of $0-30$ and $30-60 \mathrm{~cm}$ to record volumetric soil water content $(\theta)$ at 10-min intervals. Sensors were installed within 0-30 cm on either compartment in the $\mathrm{PRD}_{\mathrm{c}}$. CS500 Humidity/Air temperature sensor and Campbell Q-7.1 was installed at $2 \mathrm{~m}$ above the ground surface in the greenhouse.

Plant physiological components. Plant physiological components including $\mathrm{P}_{\mathrm{n}}$ and $g_{\mathrm{S}}$ were measured using LI-6400 XT portable photosynthesis system (LI-COR Biosciences, Lincoln, NE). These measurements were carried out on three topmost fully developed, illuminated, and healthy leaves per treatment between $9 \mathrm{AM}$ and $10 \mathrm{AM}$ on clear sunny days, five times during both growing seasons. Sampled leaves were clamped into leaf chamber and stable readings were recorded. The average of three values per treatment on each measurement date was used for statistical analysis.

Stem water potential $\left(\Psi_{\text {stem }}\right)$ was also measured on bagged leaves using pressure bomb (PMS Instrument Company, Albany, OR) three times at monthly interval during both growing seasons to quantify plant stress. Two pressure bomb readings were taken one before the start of irrigation while the other at the end of the irrigation. The sampled leaves were healthy shoots at sunlit side of the canopy. It is a destructive technique therefore only one bagged leaf per treatment was used at every measurement.

Plant height and RLD. Plant height was measured manually throughout the growing seasons at fortnight intervals. At each measurement, height was measured from the soil surface to the top of the main plant stem. For root measurements, intact roots were washed manually from all three treatment containers. Before scanning, roots were divided into segments and spread out on a transparent glass tray containing water. Root segments were scanned into tiff images using Epson Perfection 3200 Photo flatbed scanner. These tiff images of root segments representing subsample were analyzed for total length with "imageJ" program. RLD values were computed using the following equation:

$$
\mathrm{RLD}=\frac{\text { Total root length }(\mathrm{cm})}{\text { Soil volume }\left(\mathrm{cm}^{3}\right)}
$$

Plant yield. Pod harvest began 110-130 d after sowing. Pods were harvested when they reached a horticulturally green mature state (pinto stage) to maintain consistency. Yield components such as the number of pods per plant, average pod weight, average pod length, and total pod weight from a plant were recorded from three replicates per treatment during both growing seasons.

Irrigation water use efficiency. IWUE was calculated as the ratio of total pod yield during the growing season from each treatment and the total irrigation water applied to that treatment. The average of the total pod yield from three replicates per treatment was used in the above calculation.

Capsaicinoids content. Capsaicin and dihydrocapsaicin concentrations were analyzed using gas chromatography with flame ionization detector (GS/FID). Three samples per treatment quantified capsaicinoid concentration during both growing seasons. All sample tissues were frozen in liquid nitrogen and lyophilized in VirTis Freezemobile research scale freezer dryer (SP Industries, Warminster, PA). Once samples dried completely, they were crushed in morter-pestel, and $1 \mathrm{~g}$ of crushed sample was extracted in $3-\mathrm{mL}$ solution of methanol. Samples were heated and stirred for $30 \mathrm{~min}$ on a hot plate stirrer. The extracts were centrifuged at the speed of $13,000 \mathrm{rpm}$ for $5 \mathrm{~min}$ to separate extract from tissue material. Clear extracts were transferred into vials and analyzed in GS/FID. The calibration curve was prepared using capsaicin natural standard (Aldrich Chemical Co., Milwaukee, WI) that contains $65 \%$ capsaicin and $35 \%$ dihydrocapsaicin.

Data analysis and statistics. The experiment was a completely randomized design. Analysis of variance was performed on $\mathrm{P}_{\mathrm{n}}$, $g_{\mathrm{S}}$, plant height, and yield using PROC GLM procedure of Statistical Analysis System software (Version 9.0; SAS Institute, Inc., Cary, NC) to detect an irrigation treatment effect. An F test was applied at each measurement date to separate the irrigation treatment effect on physiological components and yield at 5\% significance level. The yearly differences were also evaluated and separated using least significant difference.

\section{Results and Discussion}

Soil water content. The diurnal changes in $\theta$ values were recorded from 29 Apr. to 
14 Oct. 2013 (15-184 DAT) and 17 Dec. 2013 to 03 May 2014 (18-156 DAT) in all three irrigation treatments (Fig. 1A-G). The $\theta$ values were slightly lower during 2014 than 2013 because of less frequent irrigations. During both seasons, trend and magnitude of $\theta$ were similar in control at both depths (Fig. 1A and D). In $\mathrm{PRD}_{\mathrm{v}}, \theta$ at the depth below $20 \mathrm{~cm}$ were consistently higher than above it (Fig. 1B and E). Variations of $\theta$ within $0-20 \mathrm{~cm}$ depth were only due to capillary rise from the depth of water application. In $\mathrm{PRD}_{\mathrm{c}}$, variations in $\theta$ were in accord with irrigation or drying of a compartment (Fig. 1C and F).

Plant physiological responses. The $\mathrm{P}_{\mathrm{n}}$ varied temporally, and $\mathrm{P}_{\mathrm{n}}$ values ranged from $9.2 \mu \mathrm{mol} \cdot \mathrm{m}^{-1} \cdot \mathrm{s}^{-1}$ on 24 May 2013 to 20.98 $\mu \mathrm{mol} \cdot \mathrm{m}^{-1} \cdot \mathrm{s}^{-1}$ on 21 July 2013 among all the treatments during both growing seasons (Fig. 2A and $\mathrm{C}$ ). There were no significant differences observed in $\mathrm{P}_{\mathrm{n}}$ among three treatments at each measurement dates (Fig. 2A and C) except on 109 DAT during 2013. On 109 DAT, $P_{n}$ value from control was significantly lower than those from PRD treatments likely due to aphid infestations in control plants. Aphid-affected plants were sprayed with green light neem-based rose defense. On 130 DAT, no significant differences were observed in $P_{n}$ values among treatments. Similarly during 2014, no significant differences were observed among three treatments on any of the five measurement dates, although lesser amounts of irrigations were applied than 2013. These $\mathrm{P}_{\mathrm{n}}$ results are in agreement with Kang et al. (2001) who reported no significant difference in $\mathrm{P}_{n}$ of hot pepper under alternate drip irrigation on partial roots. Similar $P_{n}$ values were reported for cotton under alternate and conventional drip irrigation treatments (Du et al., 2008). Similar $\mathrm{P}_{\mathrm{n}}$ values were also reported for maize crop under alternate and conventional furrow irrigation system in arid northwest China (Du et al., 2010).

Stomatal conductance also showed temporal variability, and $g_{\mathrm{S}}$ values for chile ranged between $0.20 \mathrm{~mol} \cdot \mathrm{m}^{-2} \cdot \mathrm{s}^{-1}$ on $08 \mathrm{Apr} .2014$ and $0.66 \mathrm{~mol} \cdot \mathrm{m}^{-2} \cdot \mathrm{s}^{-1}$ on $22 \mathrm{Aug}$. 2013 among all the treatments during both growing seasons (Fig. 2B and D). However, no significant differences in $g_{\mathrm{S}}$ were observed among the treatments, at any measurement date (Fig. 2B and D). Saeed et al. (2008) also reported no significant differences in $g_{\mathrm{S}}$ values among control, deficit (both sides irrigated at $50 \%$ of field capacity), and PRD (alternate irrigation at field capacity) treatments for potatoes.

To meet the peak water demand, chile plants under both PRD treatments seemed to compensate for water stress in the drier part of the root system by extracting more water from the wetter part. During both growing seasons, the available water calculated below $20 \mathrm{~cm}$ depth in $\mathrm{PRD}_{\mathrm{v}}$ was $5-6 \mathrm{~cm}$. This was more than the maximum transpiration rate of about $1 \mathrm{~cm} / \mathrm{d}$. In the $\mathrm{PRD}_{\mathrm{v}}$ treatment, roots seem to take up more water from the depths below $20 \mathrm{~cm}$ than above it to maintain the $\mathrm{P}_{\mathrm{n}}$ at the same level as plants grown in the
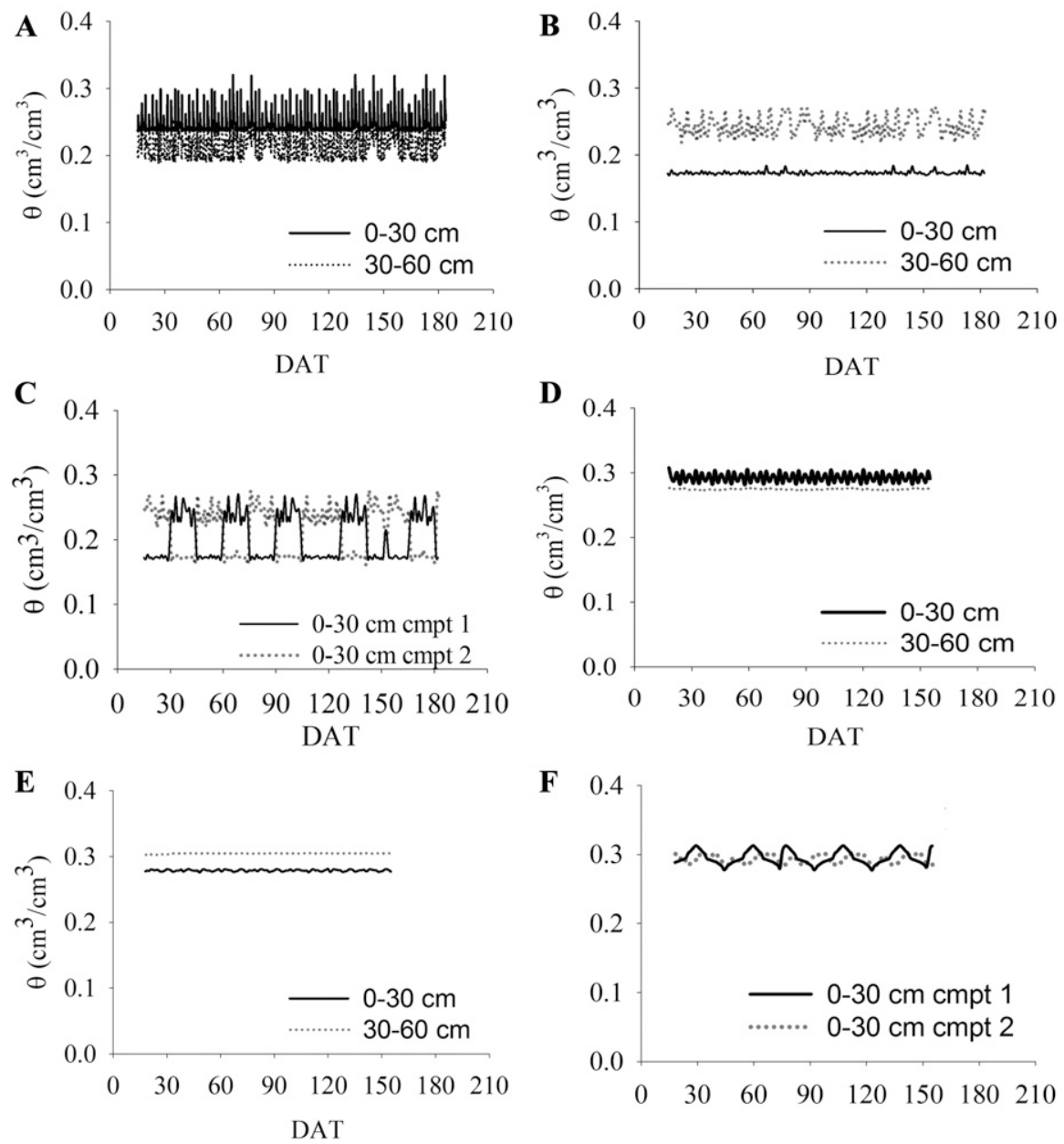

Fig. 1. Changes in soil water content (q) among three treatments: $(\mathbf{A}, \mathbf{D})$ control, $(\mathbf{B}, \mathbf{E})$ partial root-zone drying vertically $\left(\mathrm{PRD}_{\mathrm{v}}\right)$, and $(\mathbf{C}, \mathbf{F})$ partial root-zone drying compartment $\left(\mathrm{PRD}_{\mathrm{c}}\right)$ during 29 Apr. 2013 to 14 Oct. 2013 [15-183 d after transplanting (DAT)] and during 17 Dec. 2013 to 4 May 2014 (18-156 DAT).
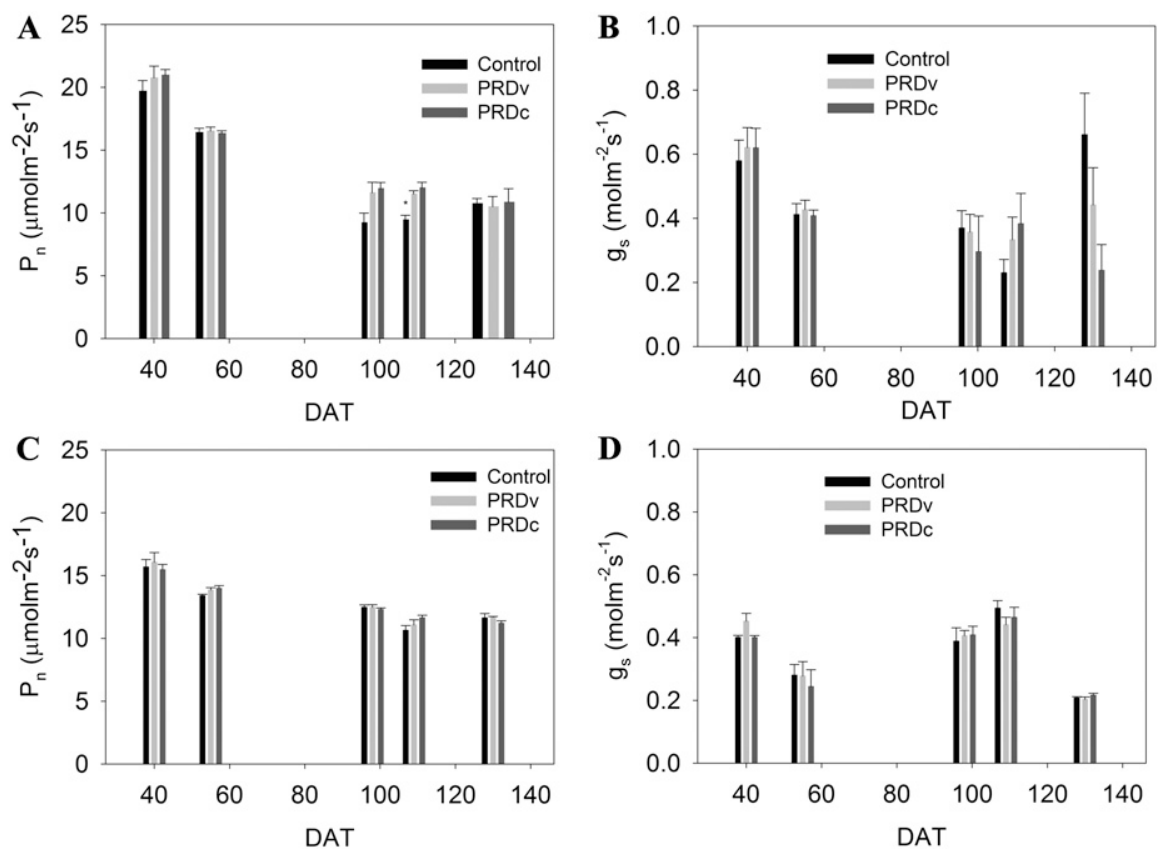

Fig. 2. (A, C) Photosynthetic rate $(\mathrm{Pn})$ and $(\mathbf{B}, \mathbf{D})$ stomatal conductance $\left(g_{\mathrm{S}}\right)$ among all three treatments, i.e., control, partial root-zone drying vertically $\left(\mathrm{PRD}_{\mathrm{v}}\right)$, and partial root-zone drying compartment $\left(\mathrm{PRD}_{\mathrm{c}}\right)$ during the growing seasons of 2013 and 2014, respectively. ${ }^{*}$ Significant difference at $P<0.05$. 
control. In the $\mathrm{PRD}_{\mathrm{c}}$ treatment, available water below $20 \mathrm{~cm}$ depth was $5-8 \mathrm{~cm}$ in the wetter compartment and roots were able to extract more water from the compartment under irrigation than the compartment under drying. In control, $39 \%$ of deep percolation water loss was recorded during growing seasons 2013, which could be used for leaching salts. However, electrical conductivity of leachate was $1.42 \pm 0.07 \mathrm{dS} \cdot \mathrm{m}^{-1}$, which falls in good range according to USDA Salinity Laboratory at Riverside, California. Therefore, deep percolation can be reduced further without any damage to crop, while simultaneously increasing water use efficiency. Therefore, during growing season of 2014 , the deep percolation was reduced to $0.91 \mathrm{~cm}$. In both years, change in water storage was higher for PRD treatments than the control and drainage was lower in PRD than control (Tables 2 and 3).

The $\Psi_{\text {stem }}$ is a sensitive indicator of water stress (Deb et al., 2012; McCutchan and Shackel, 1992; Sdoodee and Somjun, 2008). Minor temporal variations in $\Psi_{\text {stem }}$ values among treatments before and after irrigation measurement event were observed during both growing seasons (Tables 4 and 5). However, no significant differences were found among the dates of sampling (Tables 4 and 5). The lower

Table 2. Soil water balance for each of the drip irrigated control and partial root-zone drying (PRD) treatments during 168-d growing period from 29 Apr. to 14 Oct. 2013 (15-183 d after transplanting).

\begin{tabular}{lcccc}
\hline Treatment & IR amount $(\mathrm{cm})$ & $\Delta \mathrm{S}(\mathrm{cm})$ & DP $(\mathrm{cm})$ & ET $(\mathrm{cm})$ \\
\hline Control & 118.83 & 7.23 & 44.98 & 66.62 \\
PRD $_{\mathrm{v}}$ & 118.83 & 7.62 & 38.64 & 72.58 \\
PRD $_{\mathrm{c}}$ & 83.18 & 5.11 & 11.57 & 66.50 \\
\hline
\end{tabular}

$\mathrm{IR}=$ irrigation; $\Delta \mathrm{S}=$ change in storage; $\mathrm{DP}=$ deep percolation; $\mathrm{ET}=$ evapotranspiration.

Table 3. Soil water balance for each of the drip-irrigated control and partial root-zone drying (PRD) treatments during 135-d growing period from 17 Dec. to 1 May 2014 (18-153 d after transplanting).

\begin{tabular}{lcccc}
\hline Treatment & IR amount $(\mathrm{cm})$ & $\Delta \mathrm{S}(\mathrm{cm})$ & DP $(\mathrm{cm})$ & ET $(\mathrm{cm})$ \\
\hline Control & 80.38 & 5.55 & 0.91 & 73.92 \\
$\mathrm{PRD}_{\mathrm{v}}$ & 55.04 & 4.68 & 0.00 & 49.45 \\
$\mathrm{PRD}_{\mathrm{c}}$ & 55.04 & 2.81 & 0.00 & 52.24 \\
\hline
\end{tabular}

$\mathrm{IR}=$ irrigation; $\Delta \mathrm{S}=$ change in storage; $\mathrm{DP}=$ deep percolation; $\mathrm{ET}=$ evapotranspiration.

Table 4. Stem water potential $\left(\Psi_{\text {stem }}\right)$ in response to treatments, i.e., control, partial root-zone drying vertically $\left(\mathrm{PRD}_{\mathrm{v}}\right)$, and partial root-zone drying compartment $\left(\mathrm{PRD}_{\mathrm{c}}\right)$ during 29 Apr. [15 days after transplanting (DAT)] to 29 Sept. (168 DAT) 2013.

\begin{tabular}{|c|c|c|c|c|c|c|}
\hline \multicolumn{7}{|c|}{ Stem water potential (MPa) } \\
\hline \multicolumn{2}{|c|}{2013} & \multicolumn{3}{|c|}{ Before irrigation } & \multicolumn{2}{|c|}{ After irrigation } \\
\hline DAT & Control & $\mathrm{PRD}_{\mathrm{v}}$ & $\mathrm{PRD}_{\mathrm{c}}$ & Control & $\mathrm{PRD}_{\mathrm{v}}$ & $\mathrm{PRD}_{\mathrm{c}}$ \\
\hline 45 & -0.493 & -0.481 & -0.490 & -0.130 & -0.127 & -0.128 \\
\hline 75 & -0.482 & -0.488 & -0.489 & -0.131 & -0.129 & -0.127 \\
\hline 105 & -0.490 & -0.488 & -0.482 & -0.131 & -0.125 & -0.120 \\
\hline
\end{tabular}

Table 5. Stem water potential $\left(\Psi_{\text {stem }}\right)$ in response to treatments i.e., control, partial root-zone drying vertically $\left(\mathrm{PRD}_{\mathrm{v}}\right)$, and partial root-zone drying compartment $\left(\mathrm{PRD}_{\mathrm{c}}\right)$ during 14 Dec. 2013 [15 days after transplanting (DAT)] to 13 April (135 DAT) 2014.

\begin{tabular}{|c|c|c|c|c|c|c|}
\hline \multicolumn{7}{|c|}{ Stem water potential $(\mathrm{MPa})$} \\
\hline \multicolumn{2}{|c|}{2014} & \multicolumn{3}{|c|}{ Before irrigation } & \multicolumn{2}{|c|}{ After irrigation } \\
\hline DAT & Control & $\mathrm{PRD}_{\mathrm{v}}$ & $\mathrm{PRD}_{\mathrm{c}}$ & Control & $\mathrm{PRD}_{\mathrm{v}}$ & $\mathrm{PRD}_{\mathrm{c}}$ \\
\hline$\overline{45}$ & -0.598 & -0.606 & -0.609 & -0.240 & -0.245 & -0.244 \\
\hline 75 & -0.594 & -0.598 & -0.597 & -0.236 & -0.240 & -0.243 \\
\hline 105 & -0.597 & -0.598 & -0.599 & -0.237 & -0.239 & -0.244 \\
\hline
\end{tabular}

(Fig. 3A and B). These results are consistent with that of Phimchan et al. (2012) who reported no significant difference in chile plant heights under control and stress treatments.

Root development is influenced by the availability and distribution of soil water (Gallardo et al., 1994; Wang et al., 2006; Wright, 2002). In control, roots were mainly concentrated in the upper $0-20 \mathrm{~cm}$ depth, while in both PRD treatments roots grew deeper to about $30 \mathrm{~cm}$ depth during first measurement during both growing seasons. Similar trends were observed during subsequent measurements as well. In $\mathrm{PRD}_{\mathrm{c}}$, the root growth and distribution were similar in both compartments. Benjamin and Nielsen (2006) also reported deeper root growth for chickpea (Cicer arietinum L.) and field pea (Pisum sativum L.) under stressed condition. The RLD in $\mathrm{PRD}_{\mathrm{v}}$ was $\approx 154 \%$ to $174 \%$ of the control while in $\mathrm{PRD}_{\mathrm{c}}$ it was $\approx 132 \%$ to $176 \%$ of the control during 2013 (Fig. 4A and B). In 2014, RLD values in $P_{R D}$ ranged from $112 \%$ to $145 \%$ of the control while in $\mathrm{PRD}_{\mathrm{c}}$ it ranged from $104 \%$ to $119 \%$. Higher RLD values were observed during 2014 because of higher water stress as compared with 2013 (Fig. 4). Higher RLD values were also observed for peanut (Arachis hypogaea L.) (Songsri et al., 2008) and maize (Kang et al., 2000) under PRD irrigation than conventional.

Yield. Number of pods per plant is a significant yield component to consider. However, no significant differences in number of pods per plant were observed among PRD treatments and control (Table 6). Although average maximum pod length of $13.50 \pm 0.75 \mathrm{~cm}$ was found in $\mathrm{PRD}_{\mathrm{v}}$, it was not significantly different from the control and $\mathrm{PRD}_{\mathrm{c}}$ in
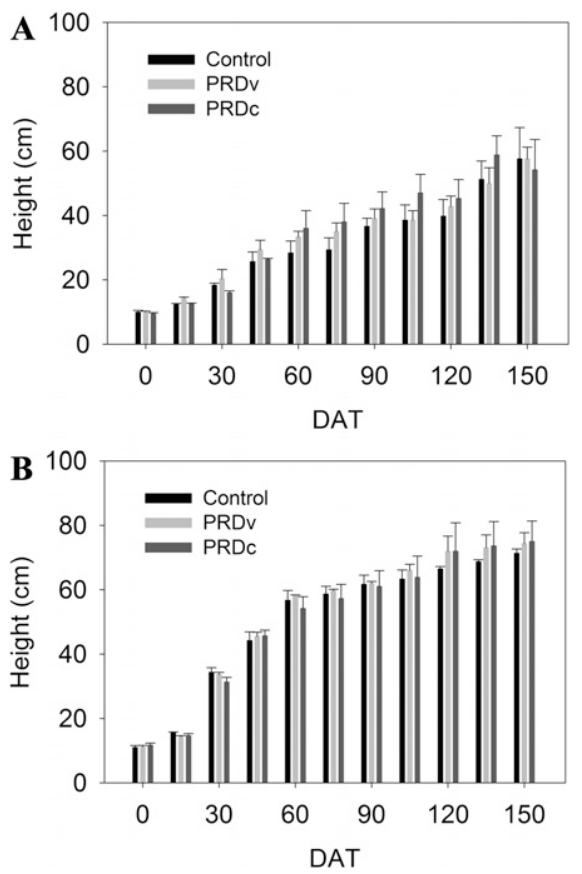

Fig. 3. Plant height $(\mathrm{cm})$ among control, partial root-zone drying vertically $\left(\mathrm{PRD}_{\mathrm{v}}\right)$, and partial root-zone drying compartment $\left(\mathrm{PRD}_{\mathrm{c}}\right)$ treatments during growing seasons (A) 2013 and (B) 2014, respectively. 

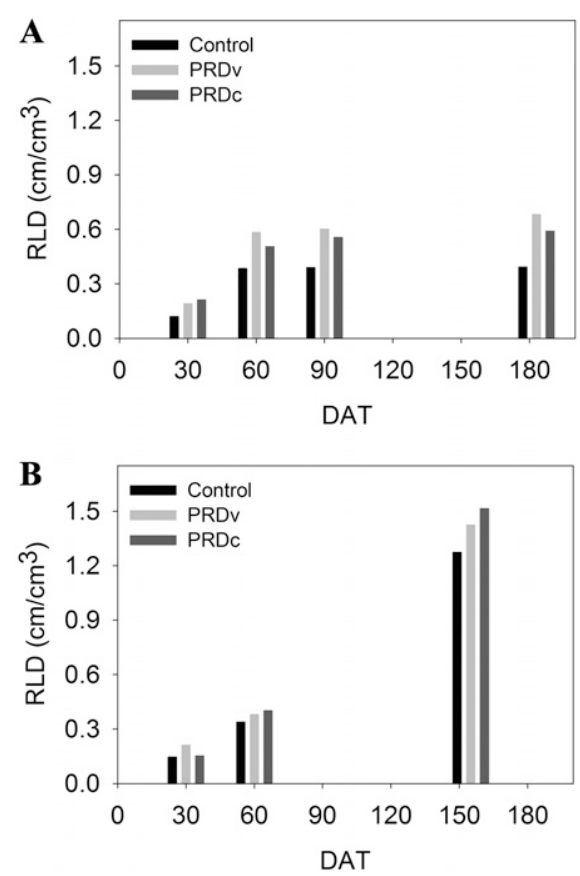

Fig. 4. Root length density (RLD) among control, partial root-zone drying vertically $\left(\mathrm{PRD}_{\mathrm{v}}\right)$, and partial root-zone drying compartment $\left(\mathrm{PRD}_{\mathrm{c}}\right)$ treatments during growing period (A) 2013 and (B) 2014, respectively.

2013. On the other hand, in 2014 , average maximum length of $12.52 \pm 0.24 \mathrm{~cm}$ was found in $\mathrm{PRD}_{\mathrm{c}}$ but again, no significant differences in pod lengths were observed among control and PRD treatments. Similarly, pod weights were also not significantly different during both growing seasons (Table 6). Average yield was calculated using 37,500 plant population/ha based on $100 \times$ $30.5 \mathrm{~cm}$ spacing, which is the most common spacing in New Mexico (Bosland and Walker, 2004). Results indicated that $P_{R D}$ and $\mathrm{PRD}_{\mathrm{c}}$ maintained the yield with up to $30 \%$ less irrigation than in control and yield, which was not significantly different among the three treatments (Table 6). These results support Kang et al. (2001) where alternate drip irrigation practice saved $40 \%$ of water without a significant yield reduction for hot pepper. In contrast, Cantore et al. (2000) observed a reduction in fresh and dry mass of sweet pepper under split-root experiment. Similarly, Dorji et al. (2005) reported a decrease in number of fruits per plant and total fresh fruit mass in PRD than control.

Irrigation water use efficiency. The decrease in yield in $\mathrm{PRD}_{\mathrm{c}}$ during 2013 was only $12 \%$ while $30 \%$ less water was applied, resulting in $26 \%$ increase in IWUE during 2013. During 2014, IWUE increased by $24 \%$ in $\mathrm{PRD}_{\mathrm{v}}$ and $31 \%$ in $\mathrm{PRD}_{\mathrm{c}}$, because less water was applied in PRD than control and yields were similar. Other studies have also reported higher IWUE of $52.05 \%$ and $61 \%$ under PRD treatments in comparison with conventional irrigation for hot peppers (Cheng et al., 2008; Kang et al., 2001).

Capsaicinoids. Capsaicinoids and dihydrocapsaicin contents were not significantly

Table 6. Various yield components (mean $\pm \mathrm{SE}$ ), i.e., average number of pods, average pod length $(\mathrm{cm})$, average pod weight $(\mathrm{g})$, and average pod yield (g/plant) for the drip-irrigated control, partial root-zone drying vertically $\left(\mathrm{PRD}_{\mathrm{v}}\right)$, and partial root-zone drying compartment $\left(\mathrm{PRD}_{\mathrm{c}}\right)$ treatments $(\mathrm{n}=3)$. Average yield $\left(\mathrm{Mg} \cdot \mathrm{ha}^{-1}\right)^{* *}$ was calculated from average pod yield (g/plant) based on having 37,500 plant population/ha during both growing seasons 2013 and 2014.

\begin{tabular}{|c|c|c|c|c|}
\hline Parameters & Season & Control & $\mathrm{PRD}_{\mathrm{v}}$ & $\mathrm{PRD}_{\mathrm{c}}$ \\
\hline \multirow{3}{*}{ Average number of pods } & 2013 & $21 \pm 3.05$ & $19 \pm 3.05$ & $17 \pm 1.73$ \\
\hline & 2014 & $24 \pm 3.79$ & $19.33 \pm 4.33$ & $19 \pm 3.51$ \\
\hline & & NS & NS & NS \\
\hline \multirow[t]{3}{*}{ Average pod length $(\mathrm{cm})$} & 2013 & $12.80 \pm 0.37$ & $13.50 \pm 0.75$ & $13.26 \pm 0.54$ \\
\hline & 2014 & $12.06 \pm 0.45$ & $12.25 \pm 0.73$ & $12.52 \pm 0.24$ \\
\hline & & NS & NS & NS \\
\hline \multirow[t]{2}{*}{ Average pod weight (g) } & $\begin{array}{l}2013 \\
2014\end{array}$ & $\begin{array}{l}30.86 \pm 2.82 \\
30.73 \pm 3.61\end{array}$ & $\begin{array}{l}31.60 \pm 2.08 \\
33.04 \pm 4.76\end{array}$ & $\begin{array}{l}33.60 \pm 3.31 \\
34.74 \pm 0.82\end{array}$ \\
\hline & & NS & NS & NS \\
\hline \multirow[t]{3}{*}{ Average pod yield (g/plant) } & 2013 & $654.06 \pm 133.29$ & $601.60 \pm 109.44$ & $578.68 \pm 109.54$ \\
\hline & 2014 & $710.31 \pm 40.44$ & $615.71 \pm 99.84$ & $654.36 \pm 103.88$ \\
\hline & & NS & NS & NS \\
\hline \multirow[t]{3}{*}{ Average yield $\left(\mathrm{Mg} \cdot \mathrm{ha}^{-1}\right)^{* *}$} & 2013 & $24.53 \pm 5.00$ & $22.56 \pm 4.10$ & $21.70 \pm 4.12$ \\
\hline & 2014 & $26.64 \pm 1.52$ & $23.09 \pm 3.74$ & $24.54 \pm 3.90$ \\
\hline & & NS & NS & NS \\
\hline
\end{tabular}

NS $=$ nonsignificant at $P \leq 0.05$.
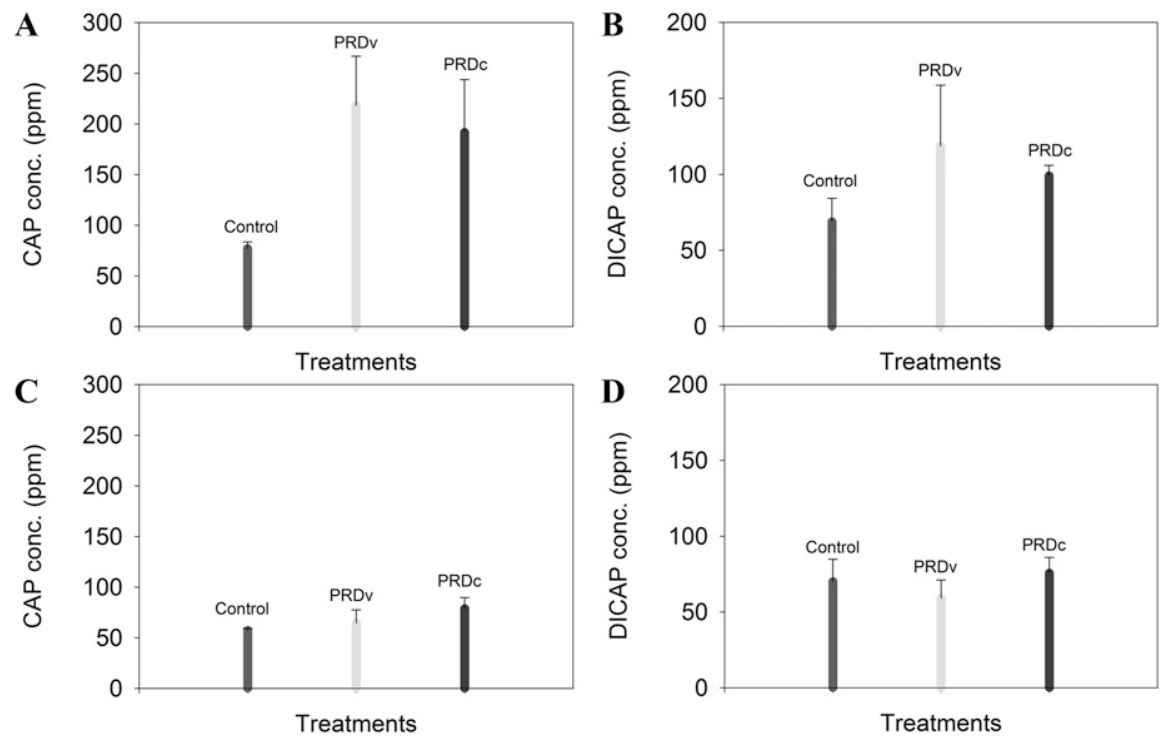

Fig. 5. (A, C) Capsaicin (CAP conc.) and (B, D) dihydrocapsaicin (DICAP conc.) among all three treatments, i.e., control, partial root-zone drying vertically $\left(\mathrm{PRD}_{\mathrm{v}}\right)$, and partial root-zone drying compartment $\left(\mathrm{PRD}_{\mathrm{c}}\right)$ during both growing seasons 2013 and 2014, respectively.

different among treatments and growing seasons $(P \leq 0.05)$ (Fig. 5A-D). In contrast, Phimchan et al. (2012) reported significantly high capsaicinoids concentrations under water stress in medium pungent chile cultivars.

\section{Conclusion}

The study evaluated the growth, physiology, yield, and capsaicinoids concentrations of chile under PRD treatments vs. control treatment. The results demonstrated that PRD could be used as an efficient irrigation method for chile production in water-limited areas. The study showed that PRD could save as much as $30 \%$ of water without significant yield reductions. Irrigation water use efficiency increased by up to $31 \%$ under dripirrigated PRD treatments. No differences in $\mathrm{P}_{\mathrm{n}}$ and $g_{\mathrm{S}}$ of chile plants among different treatments suggested that chile plants under
$\mathrm{PRD}_{\mathrm{v}}$ and $\mathrm{PRD}_{\mathrm{c}}$ compensated for water stress in drier part of the vertical or lateral root-zone profile by taking up more water from the wetter parts of the root zone to meet their ET demands. In $\mathrm{PRD}_{\mathrm{v}}$ and $\mathrm{PRD}_{\mathrm{c}}$, roots grew deeper than control and were concentrated mainly in the deeper depths where more water was available. The compensated root water uptake was also evident by the similar water stress indicated by similar stem water potential in PRD as well as control. Results demonstrated that PRD techniques have water saving potential along with high quality chile production under water-limited arid environments.

\section{Literature Cited}

Antony, E. and R.B. Singandhupe. 2004. Impact of drip and surface irrigation on growth, yield and WUE of capsicum (Capsicum annuum L.). Agr. Water Mgt. 65:121-132. 
Benjamin, J.G. and D.C. Nielsen. 2006. Water deficit effects on root distribution of soybean, field pea and chickpea. Field Crops Res. 97:248-253.

Bosland, P.W. and S. Walker. 2004. Growing chiles in New Mexico. College of Agriculture and Home Economics, Guide H-230.

Cantore, V., F. Boari, and A. Caliandro. 2000. Effect of split-root-system water stress on physiological and morphological aspects of pepper (Capsicum annuum L.). Acta Hort. 537:321-328.

Cheng, S.G., Z.Y. Zhang, N. Liu, S.E. Yu, and X. W. Gang. 2008. Comparative effects of deficit irrigation (DI) and partial rootzone drying (PRD) on soil water distribution, water use, growth and yield in greenhouse grown hot pepper. Sci. Hort. 119:11-16.

Deb, S.K., M.K. Shukla, and J.G. Mexal. 2011. Numerical modeling of water fluxes in the root zone of a mature pecan orchard. Soil Sci. Soc. Amer. J. 75:1667-1680.

Deb, S.K., M.K. Shukla, and J.G. Mexal. 2012. Estimating midday leaf and stem water potentials of mature pecan trees from soil water content and climatic parameters. HortScience 47:907-916.

Della Costa, L. and G. Gianquinto. 2002. Water stress and watertable depth influence yield, water use efficiency, and nitrogen recovery in bell pepper lysimeter studies. Austral. J. Agr. Res. 53:201-210.

Doorenbos, J. and A.H. Kassam. 1979. Yield response of water. Food and Agriculture Organization (FAO) Irrigation and Drainage Paper 33, Rome.

Dorji, K., M.H. Behboudian, and J.A. ZegbeDominguenz. 2005. Water relations, growth, yield, and fruit quality of hot pepper under deficit irrigation and partial rootzone drying. Sci. Hort. 104:137-149.

Du, T., S. Kang, J. Sun, X. Zhang, and J. Zhang. 2010. An improved water use efficiency of cereals under temporal and spatial deficit irrigation in north China. Agr. Water Mgt. 97:66-74.

Du, T., S. Kang, J. Zhang, and F. Li. 2008. Water use and yield responses of cotton to alternate partial root-zone drip irrigation in the arid area of north-west China. Irr. Sci. 26:147-159.

Dugo, V.G., F. Orgar, and E. Fereres. 2007. Responses of pepper to deficit irrigation for paprika production. Sci. Hort. 114:77-82.

Gallardo, M., N.C. Turner, and C. Ludwig. 1994. Water relations, gas exchange, and abscisic acid content of Lupinus cosentinii leaves in response to drying different proportions of the root system. J. Expt. Bot. 45:909-918.

Green, S.R. and B.E. Clothier. 1999. The root zone dynamics of water uptake by a mature apple tree. Plant Soil 206:61-77.

Green, S.R., B.E. Clothier, and D.J. McLeod. 1997. The response of water flow in apple roots to localised irrigation. Agr. Water Mgt. 33:63-78.

Hall, T. Y. and R.K. Skaggs. 2003. New Mexico's chile pepper industry: Chile types and product sourcing. New Mexico Chile Task Force Report 8.

Kang, S., L. Zhang, X. Hu, Z. Li, and P. Jerie. 2001. An improved water use efficiency for hot pepper grown under controlled alternate drip irrigation on partial roots. Sci. Hort. 89:257-267.

Kang, S.Z., Z.S. Liang, Y.H. Pan, P.Z. Shi, and J.H Zhang. 2000. Alternate furrow irrigation for maize production in an arid area. Agr. Water Mgt. 45:267-274.

Liu, F., C.R. Jensen, and M.N. Andersen. 2005. A review of drought adaptation in crop plants: Changes in vegetative and reproductive physiology induced by ABA-based chemical signals. Austral. J. Agr. Res. 56:1245-1252.

McCutchan, H. and K.A. Shackel. 1992. Stemwater potential as a sensitive indicator of water stress in prune trees (Prunus domestica L. cv. French). J. Amer. Soc. Hort. Sci. 117:607-611.

Mousavi, S.F., S.S. Gerdefaramarzi, and B.M Fard. 2010. Effects of partial rootzone drying on yield, yield components, and irrigation water use efficiency of canola (Brassica napus L.). Paddy Water Environ. 8:157-163.

Murray, M.W. 1999. Crop profile for peppers (chile) in New Mexico. New Mexico Coop. Ext. Serv., Plant Sci. Depart., Las Cruces, NM.

Phimchan, P., S. Techawongstien, S. Chanthai, and P.W. Bosland. 2012. Impact of drought stress on the accumulation of capsaicinoids in Capsicum cultivars with different initial capsaicinoids levels. HortScience 47:1204-1209.

Rahman, M.J. and H. Inden. 2012. Effect of nutrient solution and temperature on capsaicin content and yield contributing characteristics in six sweet pepper (Capsicum annuum L.) cultivars. J. Food Agr. Environ. 10:524-529.

Saeed, H., I.G. Grove, P.S. Kettlewell, and N.W. Hall. 2008. Potential of partial root zone drying as an alternative irrigating technique for potatoes (Solanum tubersum). Ann. Appl. Biol. 152:71-80.
Sepaskhah, A.R. and S.H. Ahmadi. 2010. A review on partial root-zone drying irrigation. Intl. J. Plant Prod. 4(4):241-258.

Sharma, P., M.K. Shukla, T.W. Sammis, R.L. Steiner, and J.G. Mexal. 2012. Nitratenitrogen leaching from three specialty crops of New Mexico under furrow irrigation system. Agr. Water Mgt. 109:71-80.

Songsri, P., S. Jogloy, N. Vorasoot, C. Akkasaeng, A. Patanothai, and C.C. Holbrook. 2008. Root distribution of draught-resistant peanut genotypes in response to drought. J. Agr. Crop Sci. 194:92-103.

Sdoodee, S. and J. Somjun. 2008. Measurement of stem water potential as a sensitive indicator of water stress in neck orange (Citrus reticulate Blanco). Songklanakarin J. Sci. Technol. 30(5): 561-564

Spreer, M., W. Nagle, S. Neidhart, R. Carle, S. Ongprasert, and J. Muller. 2007. Effect of regulated deficit irrigation and partial rootzone drying on the quality of mango fruits (Mangifera indica L., cv. 'Chok Anan'). Agr. Water Mgt. 88:173-180.

Stoll, M., B.R. Loveys, and P. Dry. 2000. Hormonal changes induced by partial root-zone drying of irrigated grapevine. J. Expt. Bot. 51:1627-1634.

Tang, L.S., Y. Li, and J.H. Zhang. 2005. Physiological and yield responses of cotton under partial rootzone irrigation. Field Crops Res. 94:214-223.

Wang, F.X., Y. Kang, and S.P. Liu. 2006. Effects of drip irrigation frequency on soil wetting pattern and potato growth in north China Plain. Agr. Water Mgt. 79:248-264.

Wierenga, P.J. 1983. Yield and quality of trickle irrigated chile. Agr. Expt. Sta. Bul. 703.

Wright, J. 2002. Irrigation scheduling checkbook method. Communication and Educational Technology Services, University of Minnesota, Minneapolis, MN.

Zamora, A.G., E.S. Campos, J.G. Luna-Ortega, R.P. Morales, J.C.R. Ortiz, and J.L. GarcíaHernández. 2013. Characterization of different capsicum varieties by evaluation of their capsaicinoids content by high performance liquid chromatography, determination of pungency and effects of pungency and effect of high temperature. Molecules 18:13471-13486.

Zegbe, J.A., M.H. Behboudian, and B.E. Clothier. 2004. Partial root zone drying is a feasible option for irrigating processing tomatoes. Agr. Water Mgt. 68:195-206. 